\title{
DEVELOPMENT OF A FLEXIBLE AND ADAPTIVE ROBOTIC CELL FOR SMALL BATCH MANUFACTURING
}

\author{
F. Vidal', M. Álvarez, R. González, I. Iglesias, R. Mouriño \\ AIMEN Technology Centre. Relva 27 A, Torneiros, 36410 Porriño, Pontevedra (Spain)
}

\begin{abstract}
The development of the manufacturing processes is evolving in parallel with the emergence of new technologies. Until now, robot technology has been very closely linked to the manufacturing of large series, commonly linked to Large Enterprises (LE), due to the need for complex positioning tools and highly skilled robot operators.

These circumstances result in extra costs if a change in the product to be processed occurs, which can not be assumed for small batches and thus presents a technological and economical barrier to robotics. To enable robotics to penetrate in this kind of demanding market, a new approach is described that defines a new concept of hyper-flexible cell.

Keywords: flexible and adaptive robotic cell, small-batch manufacturing, robotics technology.
\end{abstract}

\section{INTRODUCTION}

Just to have an idea of the important role played by SMEs, in the European Union (EU), the number of manufacturing businesses is about $10 \%$ of 26 million companies (classified as NACE D3), i.e. around 2.5 million, of which $99 \%$ are SMEs (93\% micro-enterprises). European manufacturing activity today represents approximately $22 \%$ of the EU Gross National Product (GNP) [1].

However, the increasing efficiency challenges are threatening manufacturing activity in SMEs. These challenges might suggest that the manufacturing sector is declining its global leadership. For example, in percentage terms, manufacturing employment is declining, and it currently represents about $18 \%$ of employment in Europe.

An important goal in fighting against the perceived trend of 'decline in manufacturing' is to help generate long-term visions for the development of new manufacturing approaches. These approaches should promote sustainable industrial growth and an improved quality of life for society as a whole. In this context, research of new manufacturing technology (for example, the adoption of robotics technology) is an important catalyst for industrial innovation [2].

Therefore, for industries to remain competitive in the increasingly complex global economic environment, it is crucial that they modernise their manufacturing base and strengthen the links between research and innovation.
Despite the fact that the automation of many manufacturing processes is possible, the deployment of current robotic systems is not cost-effective in the case of Small and Medium-Sized Enterprises (SMEs) due to small batch sizes. This fact presents a technological and economical barrier to the automation of many manufacturing processes in SMEs or non-traditional industries. Furthermore, SMEs have difficulty finding skilled workers capable of operating robots, therefore, new and more intuitive ways for people to interact with robots are required to make robot programming easier and accessible [3].

To enable robotics to penetrate in this kind of demanding market, a novel system -involving sensorics and software for control and path planning- has been developed and integrated to define a new concept of hyper-flexible cell.

The flexible robotic system proposed consists of an industrial robot that can be easily extended with external sensors to influence the robot trajectory in real-time [4] (Figure 1). Such a system is flexible to production changes by being easily reconfigurable with additional sensors (e.g. force and vision sensors) and adaptive to variances within a production process by adjusting the robot trajector$y$ in real-time with the additional information obtained by these sensors [5].

Grinding, polishing and deburring are examples of industrial tasks involving interaction of the robot tool with a workpiece or a surface, for which the interaction force between the tool and the environment must be controlled $[6,7]$. 


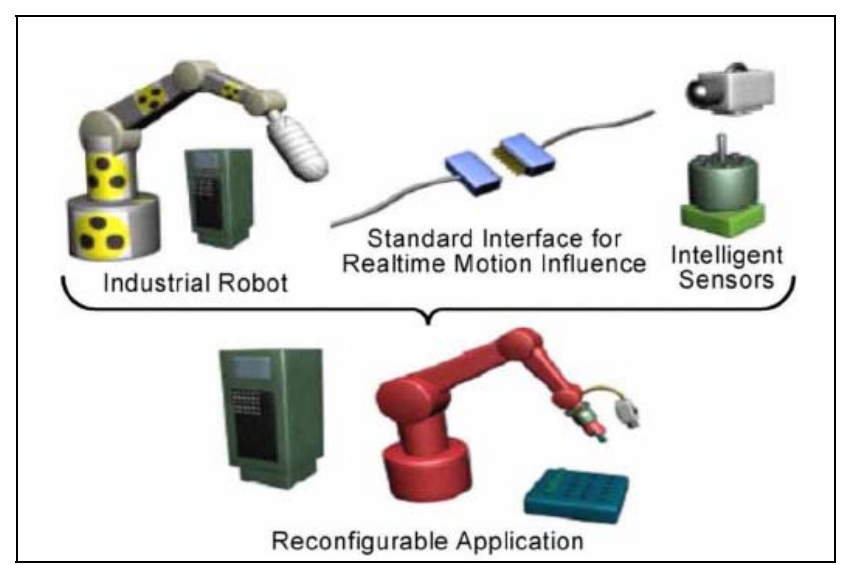

Figure 1. Scheme of a Flexible and Adaptive Robotic Cell

At this moment, weld bead grinding is typically a laborious manual operation that involves, in medium sized structures, the full dedication of an average of 2-3 specialized workers for about 20-35\% of production man-hours (Figure 2).

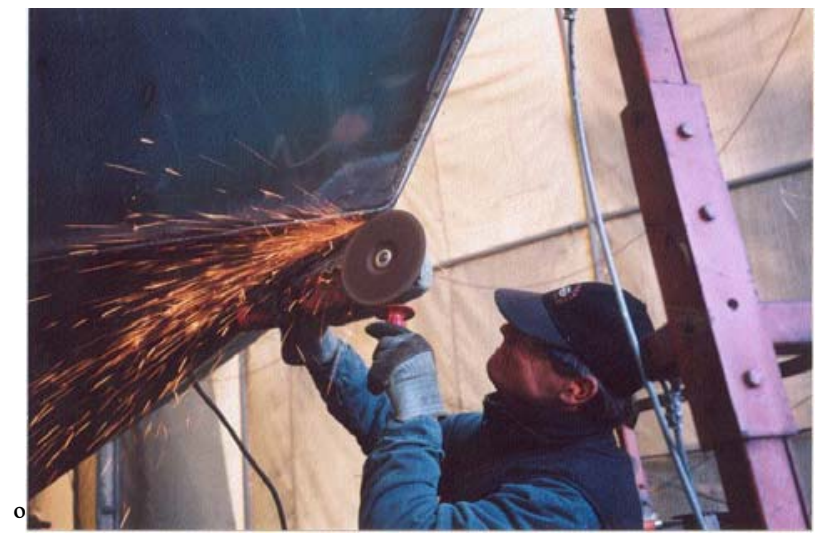

Figure 2. Manual Weld-bead grinding in medium sized structures

Therefore, a new hyper-flexible cell with capability of "environment knowledge" has to be developed, allowing the robot to locate, identify and readapt the weld bead grinding not only to different products, but also to tolerance variations of the parts. With a flexible robotic system the contact force between the cutting tool and the surface can be controlled by integrating an intelligent force sensor, while the actual robot position can be obtained and modified with a high absolute accuracy by means of external smart cameras and markers [8]. The external sensors also allow the system to be quickly reprogrammed to production changes, such as different shape and size of the product.

\section{EXPERIMENTAL PROCEDURE}

The main objective of the work presented is the development of an "open robotic cell" that will be able to make polishing and weld grinding operations in different large structures. The work is specifically focused on a weld bead grinding application.

As an example, in naval applications, when the weld bead is exposed to the sea, the efficiency and the robustness of a structure depends on the geometry and the homogeneity of the surface finishes, and in general all the dimensional specifications play a crucial role. To fulfill these requirements, grinding and polishing should be carefully applied to the weld beads in order to ensure the best fit of the real structure to the theoretical -specified- form.

Such requirements increase the manufacturing costs due to the manual characteristics of the grinding and polishing processes. Currently, the process is laborious, slow and subject to operator performance, which poses accuracy and quality concerns. Besides, this work should be developed in harsh conditions.

Thus, a Flexible Robotic Cell with adaptive capabilities will increase the productivity and the competitiveness of this manufacturing process, improving the working conditions of operators and the quality of the final part. The proposed robotic cell involves the following developments:

- Intuitive robot programming based on CAD,

- A system for detection and accurate location to re-adjust the robot trajectory,

- A force control system that guarantees the necessary contact pressure with the part to grind.

\subsection{Intuitive robot programming based on CAD}

Small batch sizes pose a particular challenge for robotic applications because of the need to programme each batch.

- Robot programming through the typical teaching method (normally, using a teach pendant) is a tedious and time-consuming task that requires technical expertise. Furthermore, as a result of the size and complexity of many marine structures, this method requires the operator to manually define all poses (robot end-effector position and orientation) on the workpiece.

- Typical Off-line programming method also involves the employment of highly skilled labour in both robotics and mechanical processes.

The solution proposed in this work is to develop methodologies that help the final users to program a robot in an intuitive way, quickly, and with a high-level of abstraction from the robot language.

Specifically, a CAD-based programming system is presented as a starting point to develop a Fle- 
xible and Adaptive Robotic Cell for small batch manufacturing (Figure 3).

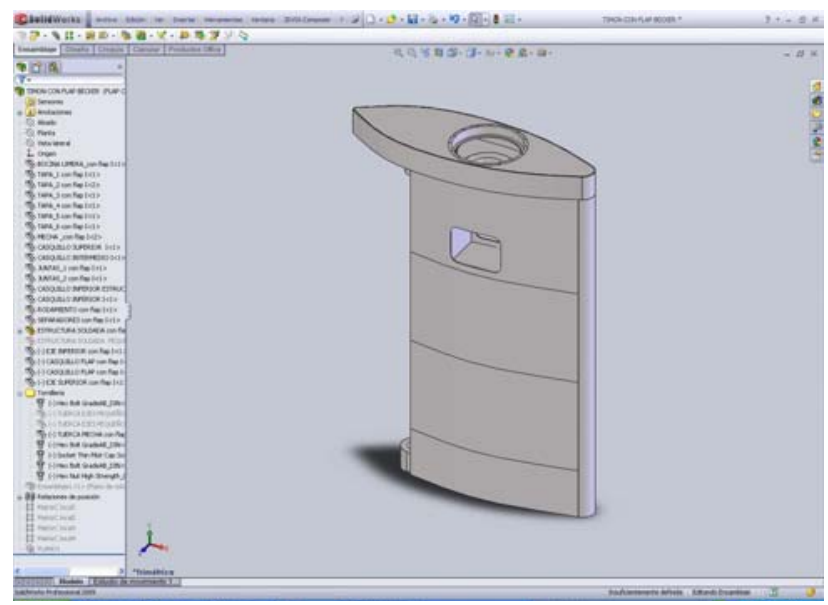

Figure 3. Example of a marine component to be ground

In this system, the operator generates the robot routine by simply drawing the robot paths of the weld beads to be ground on the CAD environment (Figure 4).

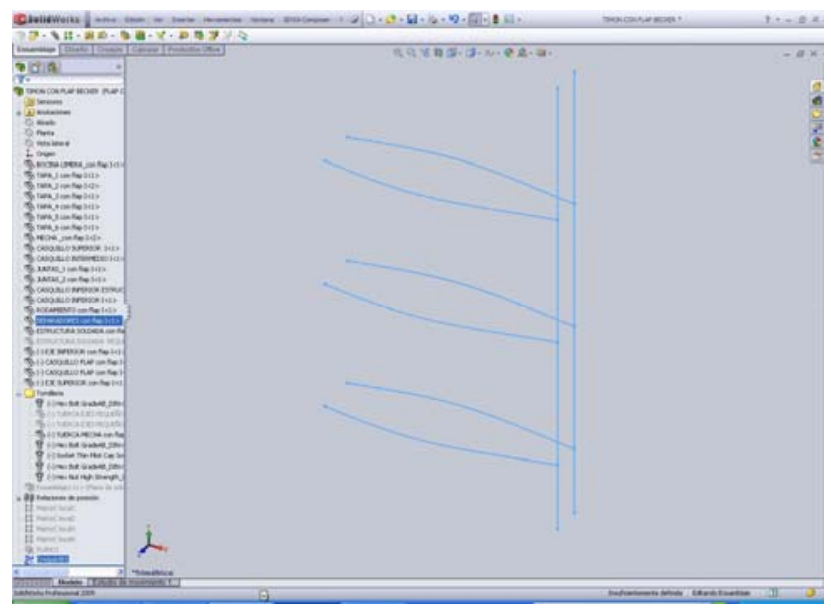

Figure 4. Paths drawn by the operator

These drawings are automatically extracted from the CAD environment. Next, they are processed to generate a robot routine with the paths (tool orientations, points and movements) where grinding and/or polishing must be applied (Figure 5).

This step makes necessary to extract the information using the Application Programming Interface (API) Model Object of the CAD platform. This API establishes a link to extract the points that characterize the lines, arcs and/or splines that have been drawn by the operator (Figure 6).

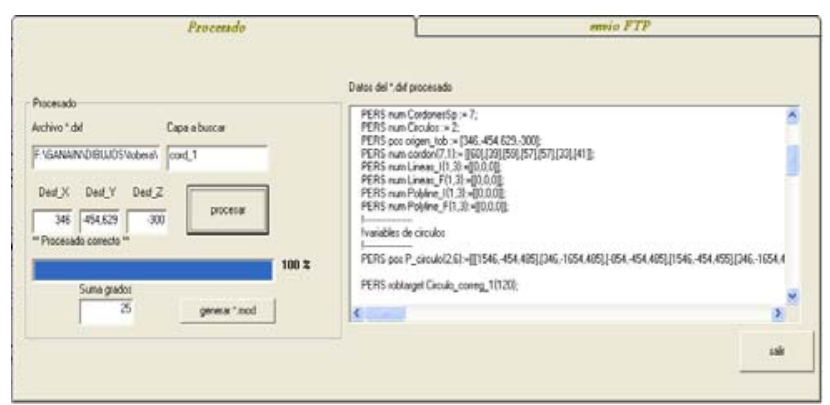

Figure 5. Robot routine automatically generated from $C A D$ model

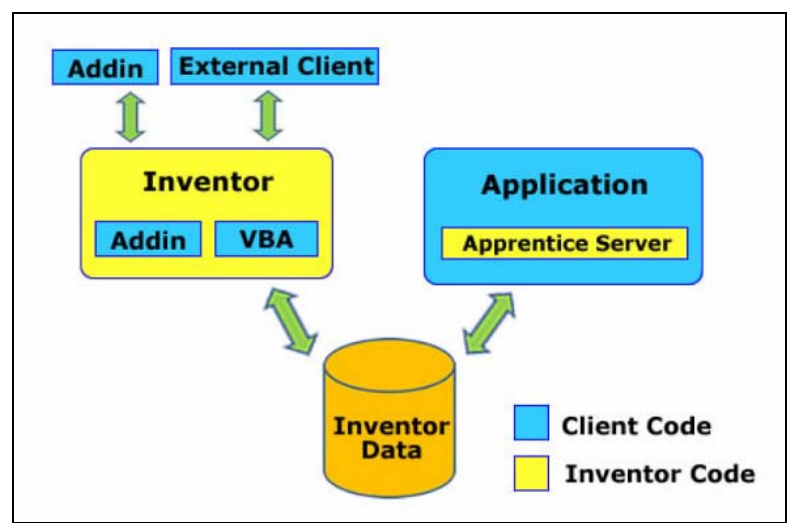

Figure 6. Accessing Autodesk Inventor ( data

All these points extracted from CAD are used to extract a, which has the best fit to a series of data points. In general, curve fitting can involve either, where an exact fit to the data is required, or smoothing, in which a smooth function is constructed that approximately fits the data. Specifically, in the work presented, a six-degree polynomial fitting was developed. The employed algorithm finds the coefficients of a polynomial $\mathrm{p}(\mathrm{x})$ of degree 6 that fits the data, $\mathrm{p}(\mathrm{x}(\mathrm{i}))$ to $\mathrm{y}(\mathrm{i})$, through a least squares computation. The result $p$ is a row vector of length $6+1$ containing the polynomial coefficients in descending powers:

$p(x)=p_{1} x^{6}+p_{2} x^{5}+\ldots+p_{6} x^{1}+p_{7}$

The Figure 7 shows the curve fitting for a longitudinal weld bead using the points provided by the CAD environment.

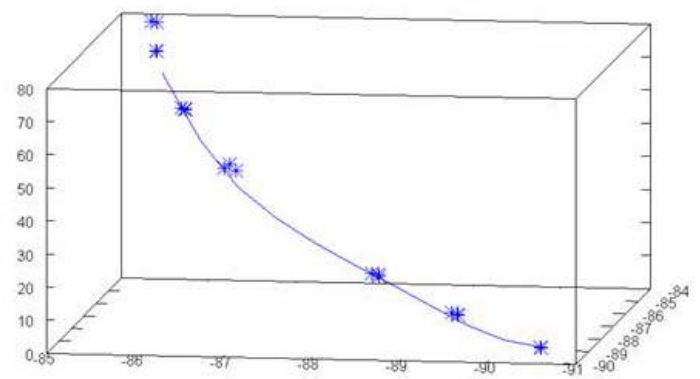

Figure 7. Curve fitting for a longitudinal weld bead 
Furthermore, to define the robot end-effector pose (position and orientation) it is necessary not only to obtain information about the $\mathrm{X}, \mathrm{Y}, \mathrm{Z}$ coordinates, but also to define the orientations along the path (Figure 8). Specifically, in the case of marine structures, the weld bead grinding process requires that the orientation of the deburring tool should be defined normal to the surface.

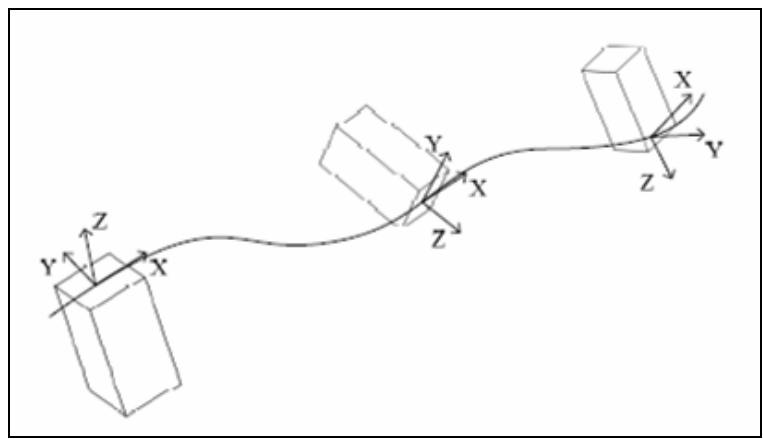

Figure 8. Robot end-effector pose

Additionally, in CAD-based programming systems a complete definition of the robot cell and robot scenario is needed. This definition includes the specification of the position and orientation of the part to be ground, respect to the robot reference system.

Besides, the robot trajectories created from a CAD environment should be readapted due to the geometric deviations of the actual part from the theoretical CAD.

\subsection{Adaptive detection and location system to re-adjust the robot trajectory}

To readapt the robot routines to geometry variations it is necessary to use external sensors (e.g. cameras) that provide the robot system with a perception of the actual configuration. These sensors should provide the information required to estimate the corrections of the path planned by the CAD-based programming system.

Specifically, in this work, a 3D vision system (camera + laser) coupled to the robot tool was integrated. This system, relying on a triangulation principle (Figure 9), analyzes the image of the laser profile in order to obtain the real position of the different weld beads to be ground and/or polished.

Therefore, the $3 \mathrm{D}$ vision system should detect and quantify variations in position, orientation, and geometry. The geometric characterization of the different welded beads requires a measure of width, thickness, and length of the same (Figure 10).

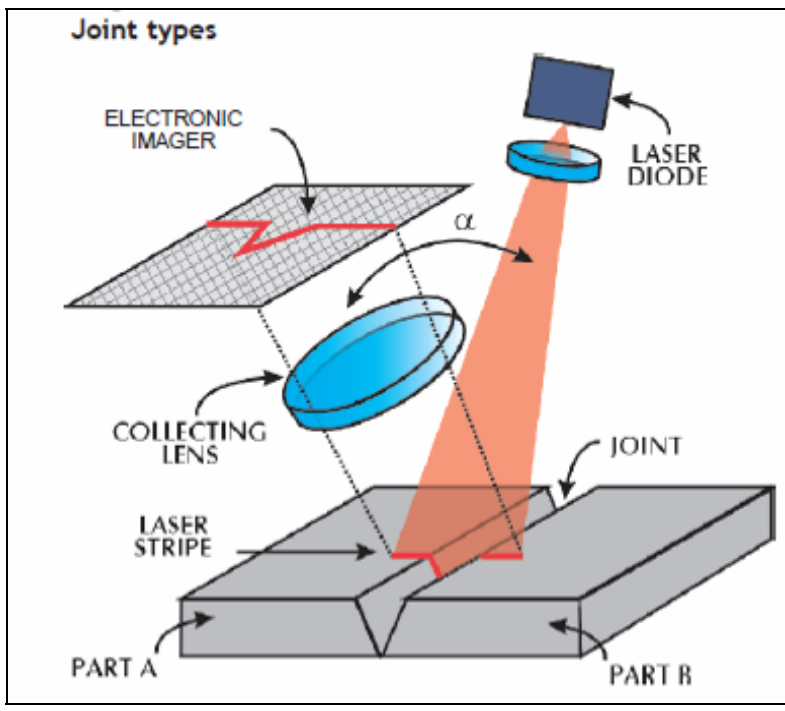

Figure 9. Principle of laser triangulation

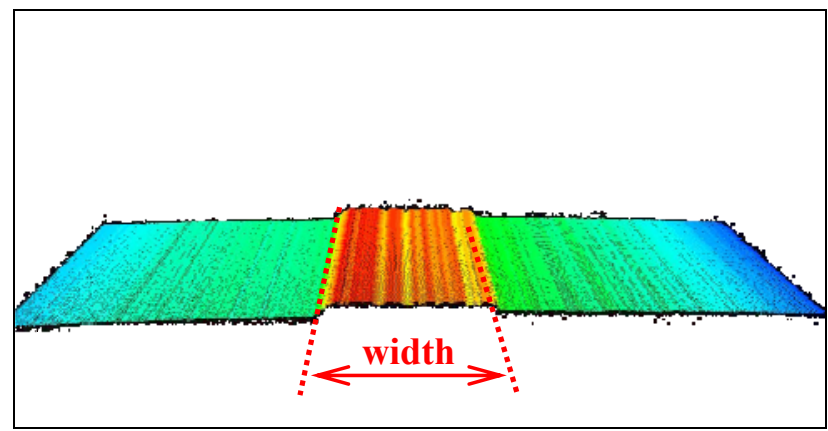

Figure 10. Geometric characterization of a weld bead

To estimate the variations in position and orientation of the different parts to be processed, a software application has been developed (Figure 11). This software processes the data obtained from the camera to extract first the deviations in the actual absolute position of the weld and after the geometric characterization of the different weld beads of the part. The machine vision system is calibrated to convert the camera coordinates to the robot world coordinates with the required accuracy.

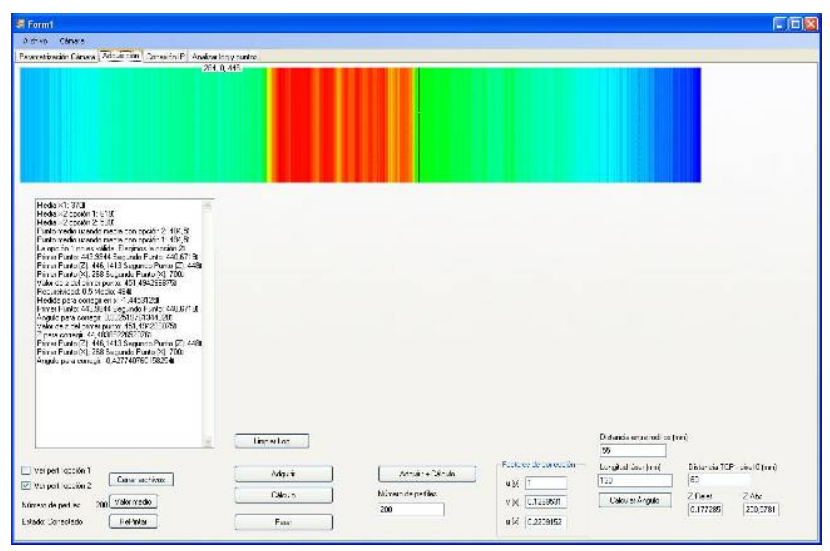

Figure 11. Software application to obtain the geometric deviations and real dimensions of the weld beads 
The goal of the vision system is to support an on-line path planner to readapt the previous off-line routines to the actual positions of the different welded beads to be ground. To do that, the information obtained by the $3 \mathrm{D}$ vision system is merged with the previous data from the off-line programming system. The new paths will guide the end-effector along the actual positions of the welded beads absorbing the deviations present in the parts to process compared to the theoretical CAD, which arise mainly from the deformations occurred during the previous welding and forming processes.

The Figure 12 shows an image of the 3D vision system mounted and integrated on the robot.

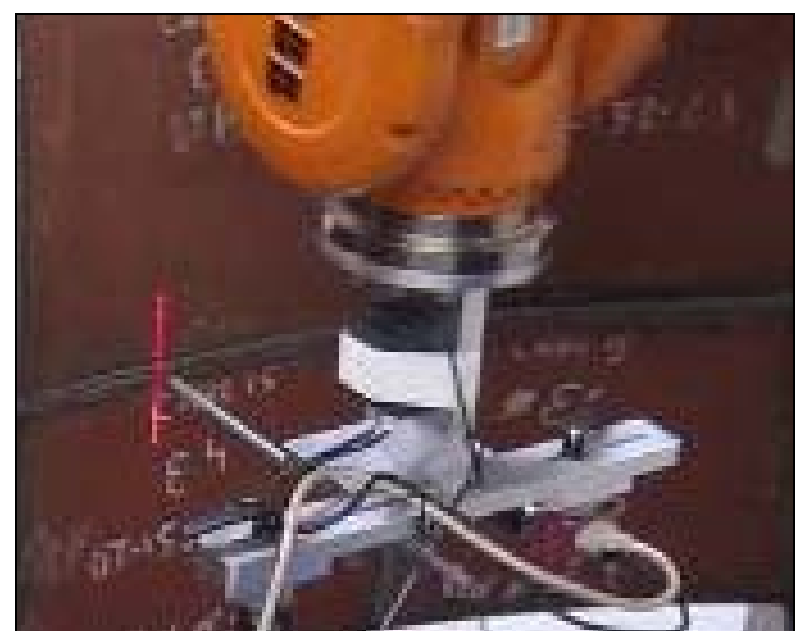

Figure 12. 3D vision system installed on the robot tool to re-adjust the robot trajectories

2.3. Force control system that guarantees the necessary contact pressure with the part to grind.

The described tasks are related to an adaptive system that allows first an intuitive CAD-based programming, and second an automated program correction relying on the sensory input provided by the machine vision system.

Additionally a real-time force control system has been developed and integrated to follow the surface to be worked, while keeping a target pushing force along the normal surface, during the weld bead grinding. Two classes of approaches may be considered:

- A through-the-arm approach based on the use of force transducers that provide, to the robot controller, real-time feedback to adjust and control the force applying along the surface. It is analogue to a human solution in which a worker applies a force and moves a tool over a surface.
- Indirect approaches based on the use of an auxiliary end-effector tool. In this case, the robotic manipulator does not modify its position, while the compliant auxiliary tool is in charge of ensuring the assigned pressure force.

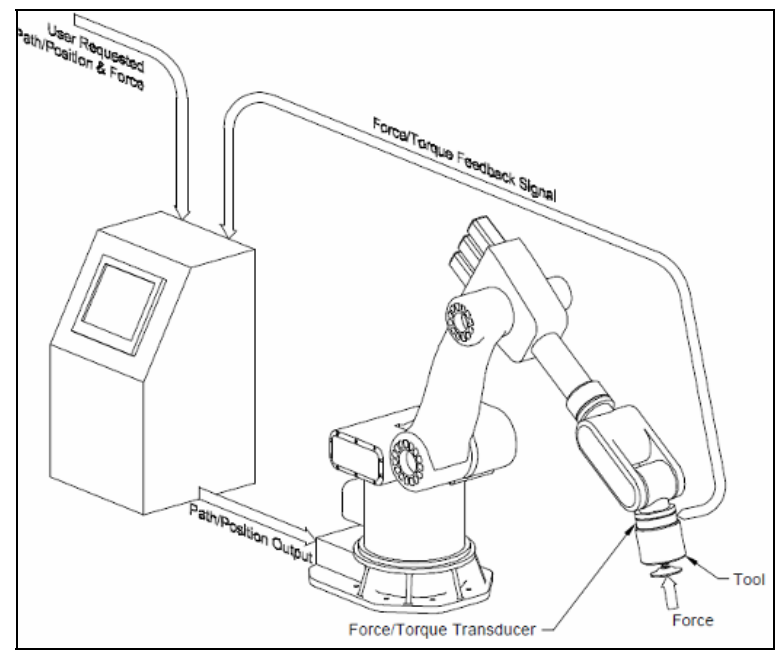

Figure 13. Through-the- arm approaches based on the use of force transducers

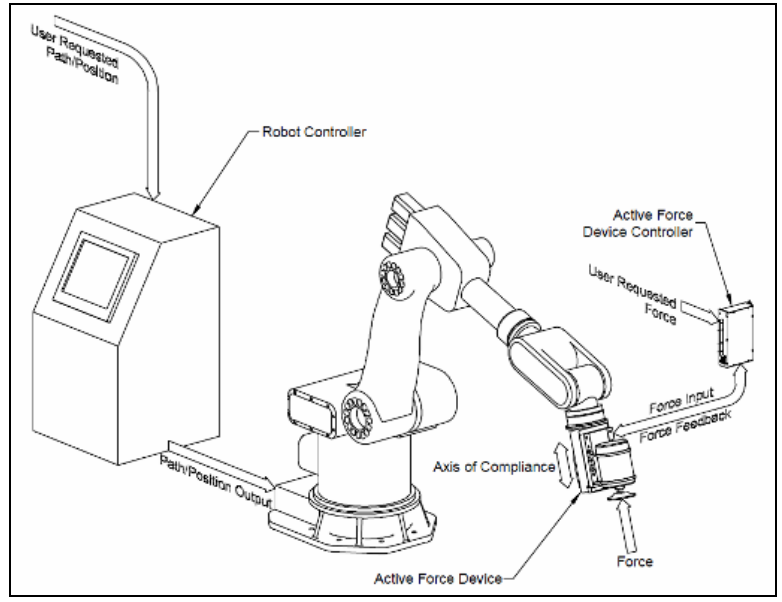

Figure 14. Approaches based on the use of an auxiliary end-effector tool

In the work presented in this paper, the second option has been adopted and the force control task has been done through the use of an auxiliary endeffector tool. The main reason is the low responsiveness of the through-the-arm approaches; in these cases an instantaneous response, for example due to a sudden rise on the surface of the part, is impossible to absorb because of the limited computation capacity of the robot controller to modify, in real-time, both position and orientation of the robot arms. Therefore, through-the-arm approaches are more useful in low speed applications with very compliant media and relatively flat parts. 
The indirect approach used in this work adds an additional linear axis of motion to the system. This axis of motion provides the compliance needed for automated surface finishing and compensates for unexpected additional material. In this work the stroke of the linear axis is $25 \mathrm{~mm}$.

The actuation method of the force control used is based in the use of a pneumatic actuator that maintains a force and compensates for position errors. This solution allows a low weight to force ratio due to the compressibility of air.

Mounting the force control device to the robot wrist requires special consideration due to the changing orientation of the axis of compliance. In this case, the force-control device should compensate the force of gravity when the tool rotates. The gravity compensation can be achieved by using a single axis accelerometer that measures the orientation angle along the carriage axis of compliance. This solution avoids the need to acquire the joint angle configuration from the robot controller.

Figure 15 shows the magnitude of the force that the actuator must apply to compensate the force of gravity as the tool rotates.

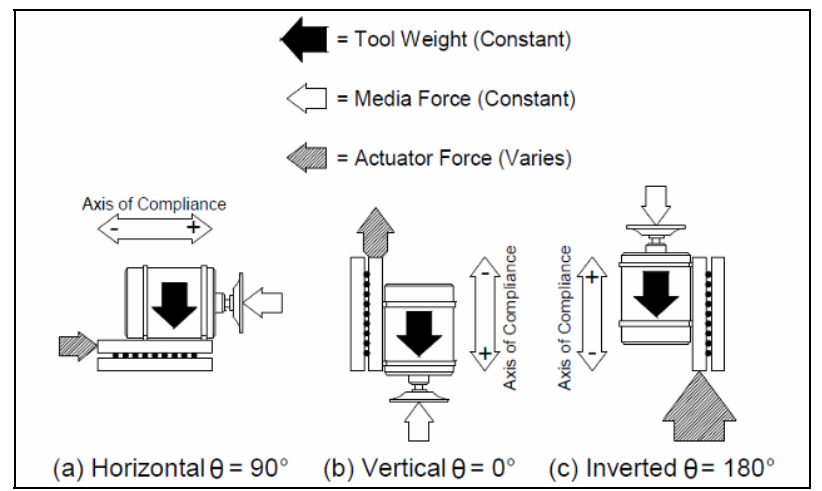

Figure 15. Effect of changing orientation on the Force Control device

Therefore, the integration in the robotic cell, of an auxiliary end-effector force control tool allows having an adaptive system that keeps constant the target pushing force along the normal surface, compensating orientation variations in curved surfaces. Figure 16 shows a picture of the pneumatic force control device used in this work for weld bead grinding.

The integration of all parts (the intuitive robot programming based on $\mathrm{CAD}$, the adaptive system to re-adjust the robot trajectory, and the force control system) completes the development of a flexible and adaptive robotic system. The actual robot positions can be obtained with high accuracy by means of external cameras, and an adaptive performance in grinding processes can be achieved with a real-time force control system. Furthermore, the CAD based pro- gramming and external sensors also allow the system to be quickly reprogrammed to deal with manufacturing changes, allowing the use for small batch manufacturing.

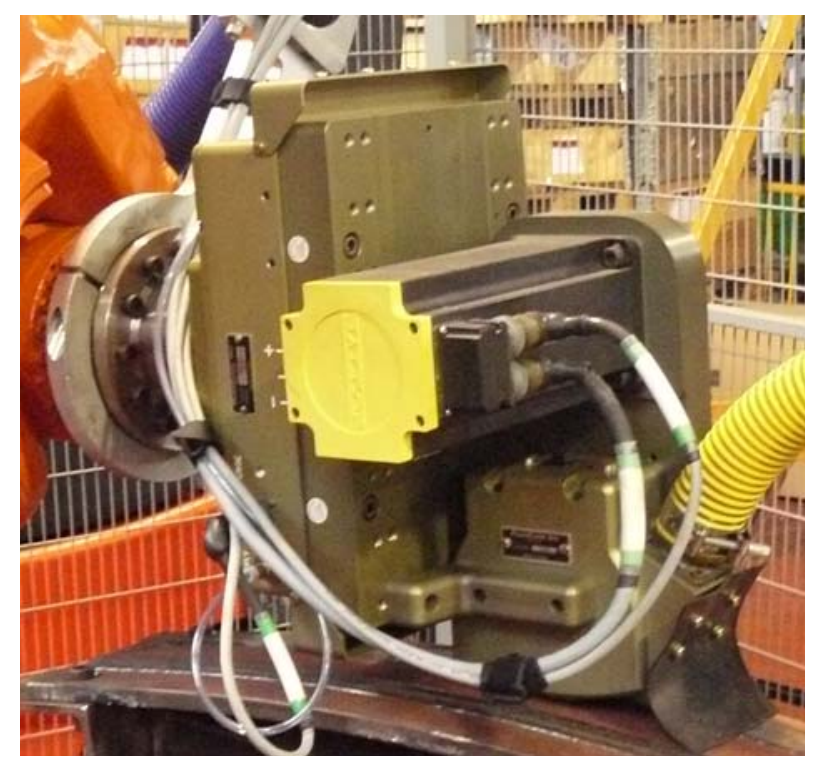

Figure 16. Pneumatic Force-Control device

Figure 17 shows a picture of the grinding process of weld beads of a demonstration component. Weld bead grinding was done by using a force of $100 \mathrm{~N}$ and with a programmed robot speed of $5 \mathrm{~mm} / \mathrm{s}$. This parameterization allows weld bead grinding through one robot pass.

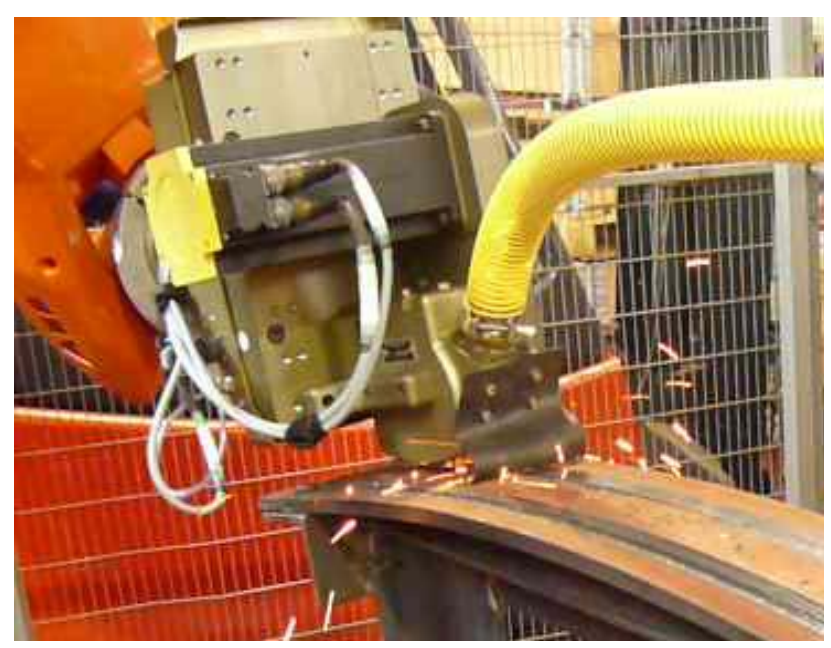

Figure 17. Weld bead grinding process

Figure 18 shows the results of a welded bead grinding process, comparing the weld bead before and after grinding process. 


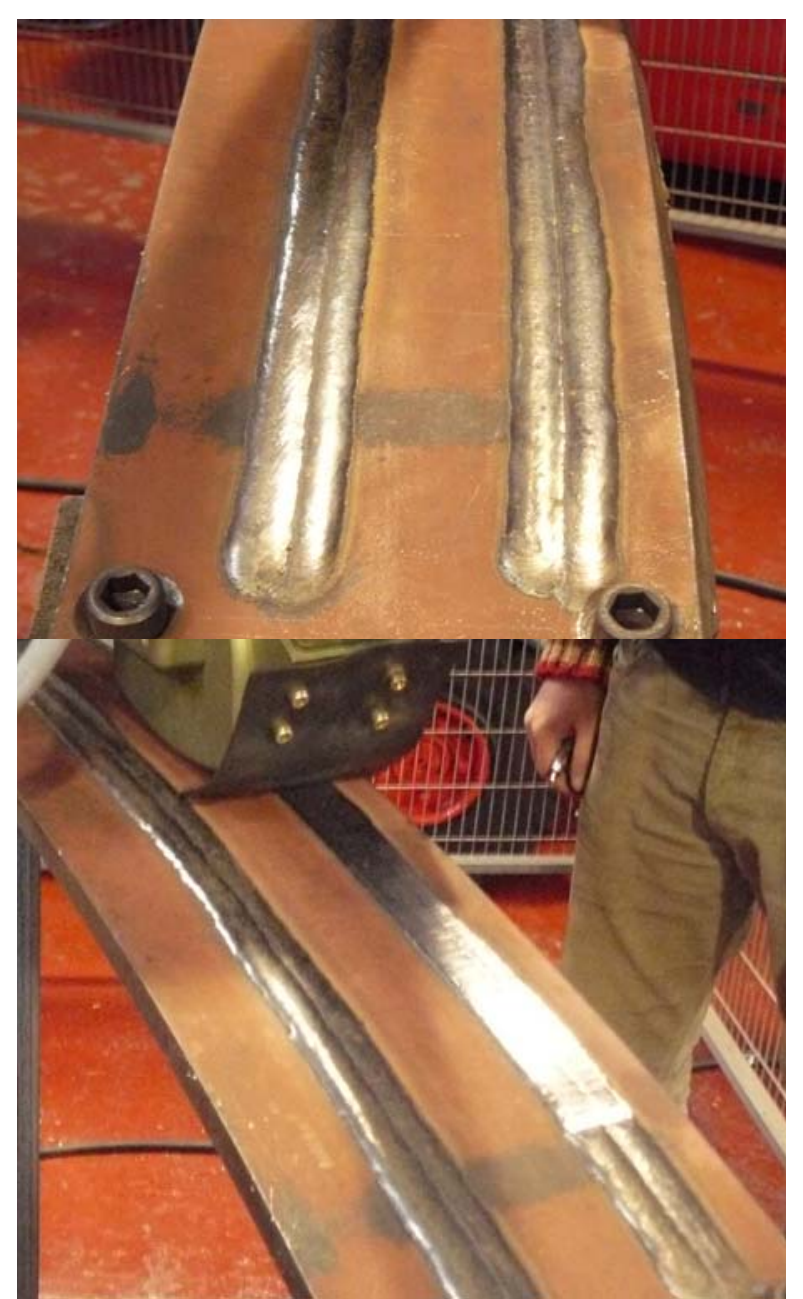

Figure 18. Comparison of weld bead before and after grinding. a) Weld bead before grinding process.

b) Weld bead after grinding process

\section{DISCUSSION}

A CAD-based robot programming system, with multisensory feedback for process control, has been developed to automate weald bead grinding. It allows a quick process programming to deal with manufacturing changes, enabling the use of industrial robots in an example of small batch manufacturing. The developed flexible robotic cell is easy to use. An operator can generate a robot routine for a specific task in few minutes, by simply drawing the robot paths of the weld beads to be ground on the $\mathrm{CAD}$ environment. There is no need for a specific training on robotics.

Furthermore, we expect that the developed system will be easily adapted to operate in different industrial processes typical of small batch manufacturing.

Therefore, the system is expected to have the following impact for final users:

- Increasing the manufacturing sector competitiveness: The context in which manufacturing en- terprises will work in the future will depend even more on flexibility and speed, as well as small-batch production.

- Increasing the technology level of the manufacturing sector: At this moment, typical operations of material ripping (like polishing, grinding, etc.) are, usually, manual time-consuming operations that challenge manufacturing efficiency and prevent the technological evolution of industrial processes.

- Decreasing, for end user, the complexity of the robotic cell.

- Decreasing the manufacturing time of the different parts: For a weld bead of $40 \mathrm{~mm}$ width and $5 \mathrm{~mm}$ over-high, the automatic grinding process decreases the manufacturing time from $30 \mathrm{~min} /$ meter (manual process) to $4 \mathrm{~min} /$ meter. Hence, it is possible to reduce a $500 \%$ in the manufacturing time.

- Improving the working conditions of operators eliminating the tedious and monotonous nature of the material ripping operations, creating greater job satisfaction. Furthermore, the working conditions would be improved as the operator would not need to do all these operations manually.

- Improving the quality of the final product, decreasing the reworking tasks: The characteristics of the hyper-flexible cell developed in this project will allow the achievement of flexible and accurate machining and ripping material operations.

The developed robot cell is expected to make a significant contribution to the necessary efforts to upgrade the production infrastructures in SME and to integrate new forms of production able to benefit from the evolving automation technologies.

Therefore, this work presents a success example to encourage the development of robotics technology focused on small batch manufacturing. Further efforts in this direction are needed to allow SME to improve cost-efficiency, performance, robustness and flexibility needed to reach a more adaptive and competitive manufacturing sector.

\section{ACKNOWLEDGEMENTS}

Authors wish to thank Xunta de Galicia for their financial support, especially through the program Fomento de la Investigación y la Innovación Empresarial del Plan Gallego de Investigación, Desarrollo e Innovación Tecnológica (INCITE) with code IN841C 2009/31. 


\section{REFERENCES}

[1]

http://ec.europa.eu/research/industrial_technologies/ pdf/nmp-expert-advisory-group report_en.pdf

[2] B. Johansson, R. Stanworth, European Manufacturing Landscape. The Creation of a Composite Capability Index for Future Manufacturing in Europe, 2005.

[3] J. N, Pires, K. Nilson and H.G. Petersen, Industrial Robotics applications and industry-academia cooperation in Europe, IEEE Robotics \& Automation, 12-3 (2005) 5-6.

[4] E. Kus, R. Grüninger, and R. Hüppi, Integration of Intelligent Sensors for Sensor-guided Motions in Industrial Robot Applications, in Proceedings of the IEEE Intemational Conference on Automation and Logistics (2005), 1450-1455.

[5] R. Grüninger, E. Kus and R. Hüppi, Market Study on Adaptive Robots for Flexible Manufac- turing Systems, Proceedings of the 2009 IEEE International Conference of Mechatonics, Malaga 2009.

[6] A. Blomdell et al., Extending an industrial robot controller: Implementation and applications of a fast open sensor interface, IEEE Robotics and Automation Magazine, 12 (2005) 85-94.

[7] A. Robertsson et al., Implementation of Industrial Robot Force Control. Case Study: High Power Stub Grinding and Deburring, Proceedings of the 2006 IEEE/RSJ International Conference on Intelligent Robots and Systems, Beijing, 2006, 2743-2748.

[8] D. Torkar, G. Papa, Robot TCP positioning with vision: accuracy estimation of a robot visual control system, Proceedings of fourth International Conference on Informatics in Control, Automation and Robotics, Angers (2007) 212-215.

$\operatorname{son}$

\section{РАЗВОЈ ФЛЕКСИБИЛНИХ И АДАПТИВНИХ РОБОТСКИХ ЋЕЛИЈА ЗА ПРОИЗВОДЮУ У МАЛИМ СЕРИЈАМА}

Сажетак: Развој производних процеса тече паралелно са појавом нових технологија. До сада је роботска технологија била нераскидиво повезана са производњом у великим серијама, углавном везаном за велика предузећа, због потребе сложеног позиционирања алата и високостручних оператера робота.

Ове околности доводе до додатних трошкова ако дође до промјене у начину обраде производа, што је теже за примјену кад су у питању мале серије и представља технолошку и економску баријеру за роботику. Како би се омогућило роботици да продре на овако захтјевно тржиште, описан је нови приступ који дефинише нови концепт хиперфлексибилне ћелије.

Кључне ријечи: флексибилна и адаптивна роботска ћелија, производња у малим серијама, технологија роботике. 